\title{
積層吸遮音材の接着による遮音性能への影響
}

\author{
黒沢 良夫*1, 山口 誉夫*2, 中泉 直之*3, 高橋 学*3
}

\section{Effect of sound insulation by adhesion of laminated sound insulation materials}

\author{
Yoshio KUROSAWA ${ }^{* 1}$, Takao YAMAGUCHI ${ }^{* 2}$, Naoyuki NAKAIZUMI*3 \\ and Manabu TAKAHASHI ${ }^{* 3}$ \\ ${ }^{* 1}$ Department of Mechanical and Precision System, Teikyo University \\ 1-1 Toyosatodai, Utsunomiya-shi, Tochigi 320-8551, Japan \\ ${ }^{* 2}$ Graduate School of Science and Technology, Gunma University \\ 1-5-1 Tenjin-cho, Kiryu-shi, Gunma 376-8515, Japan \\ ${ }^{*}$ Sound Proof Technical Department, Asahi Rubber Co., Ltd. \\ 15 Kitane, Fukaya-shi, Saitama 369-1242, Japan
}

\section{Received 15 December 2015}

\begin{abstract}
This report shows effect of sound insulation by adhesion of porous materials and film laminated panel. It deals a technique for estimating damped vibration of automotive body panels with sound-proof structures. It calculates damping properties for sound-proof structures involving elastic body, viscoelastic body and Biot type porous materials by three-dimensional finite element method. In this analysis, particle displacement vectors for internal air in the porous materials are adopted as unknowns for the discretized equations for finite element method. And displacement vectors for frame in the porous materials are also selected as the unknowns. A numerical code is developed. For numerical examples, Biot type porous materials are sandwiched between panel and film, and laminated film. Frequency response functions were calculated for panels laminated with porous material (felt) and viscoelastic body (film) and porous material (felt) using this technique, the calculation results almost agreed with the experimental results. And effect of the vibration performance by with/without adhesion is clarified. At with adhesion, the internal air and the frame in the porous material are same vibration. But at without adhesion, the internal air and the frame in the porous material are greatly different vibration. It is thought that change of sound insulation takes place by this.
\end{abstract}

Key words : Finite element method, Damping, Porous material, Transmission loss, Automobile

\section{1. 緒言}

近年，自動車の性能として車内快適性が重視され，さらなる車内の静肃性が求められている。例えば，エンジ ンルームと車室を隔てているパネル（以下トーボード：図 1）は，エンジン騒音を防ぐため防音対策が厳重にな されている，トーボードは鋼板を所要の形状にプレス成形して作られ，その上には，従来フェルト・ウレタン等 からなる吸音材 (多孔体) と，樹脂シートからなる表皮（粘弾性体）が積層されており，2 重壁構造による遮音 性能を実現していた。しかし，トーボードにはステアリングやハーネスやダクト等の貫通部品やエアコンやヒー ターユニット等設置部品も多く, 穴や吸音材が十分スペースを取れない部分もあり，軽量化も考慮して吸音性能 を重視した密度の小さい多孔体に密度の高い多孔体を配置した積層吸遮音材も用いられるようになってきた。こ

\footnotetext{
No.15-00664 [DOI:10.1299/transjsme.15-00664], J-STAGE Advance Publication date : 9 May, 2016

*1 正員，帝京大学 理工学部( $=320-8551$ 杤木県宇都宮市豊郷台 1-1)

*2 正員, 群馬大学 理工学部( ⿳376-8515 群馬県桐生市天神町 1-5-1)

*3 アサヒゴム (株) 防音技術部(干369-1242 埼玉県深谷市北根 15)

E-mail of corresponding author: ykurosawa@mps.teikyo-u.ac.jp
} 
のタイプの吸遮音材は多孔体と多孔体の間に樹脂シートやフィルム（厚さ数 $10 \mu \mathrm{m}$ 程度のオレフィンシート）を 挟んだタイプも多いが，多孔体とフィルムの接着の有無で遮音性能が大きく変化することがわかってきた（黒沢 他, 2013).

著者らはまず，多孔体の内部空気のみをモデル化した有限要素法（山口他，2003）（山口他，2005）を用いて解 析を行ったが，接着の有無による遮音性能の変化は再現できなかった（黒沢他，2013）。そのため，多孔体を内部 空気と骨格の両方の波動の伝播を考慮する弾性多孔体とした（Biot, 1955）伝達マトリックス法(Allard and Atalla, 2009)を用いた数值計算を行い，接着の有無による遮音性能の変化は再現できてきた（黒沢他，2014）. しかし， どのようなメカニズムで接着の有無により遮音性能の変化が起こっているかは解明できていなかった.

Bolton らは多孔体の骨格の変位と内部空気の粒子変位を未知数とする有限要素法による離散化方程式を導いて いる (Kang and Bolton, 1996). Atalla らは骨格の変位と内部空気の圧力を未知数とする有限要素法による離散化方 程式を導いている（Atalla and Gardner, 2001）。本論文では，著者の一部らが作成した多孔体の内部空気と骨格の 両方の波動が伝播できる有限要素を用いた数值解析手法（山口他，2006）を用いて計算を行った．本手法の特徵 は，弾性体や粘弾性体と多孔体が接続される場合に共通のパラメータ（変位）のみで記述できるので，境界条件 のモデル化が容易にできることである．また，このような連成問題の変位応答分布を直接計算・表示できること である.しかし, Atalla らの定式化と比較すると, 圧力は 1 次元に対し粒子変位は 3 次元になり計算自由度が多 く計算時間がかかる欠点もある. 本手法を使って, 積層吸遮音材の振動解析を行い, 半無響室に設置された簡易 的な遮音性能計測装置を用いた遮音性能や振動の計測結果と計算結果の比較, さらにフェルトとフィルム接着の 有無の影響について報告する.
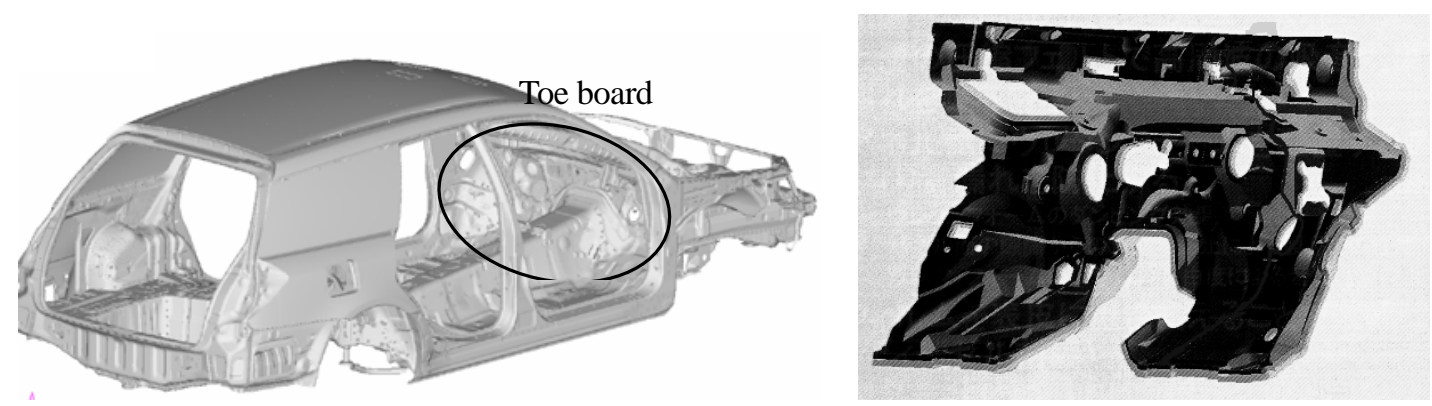

Fig.1 Toe board Insulator of automotive panel

\section{2. 解析手法}

\section{$2 \cdot 1$ 弾性多孔体の内部空気と骨格に関する振動場の離散化}

内部空気の粒子変位ベクトルと骨格の変位ベクトルをそれぞれ

$$
\{U\}=\left\{\begin{array}{l}
U_{x} \\
U_{y} \\
U_{z}
\end{array}\right\} \quad\{u\}=\left\{\begin{array}{l}
u_{x} \\
u_{y} \\
u_{z}
\end{array}\right\}
$$

とすると, 内部空気に関する運動方程式は以下となる.

$$
\begin{aligned}
& \frac{\partial^{2}}{\partial t^{2}}\left(\rho_{21} u_{x}+\rho_{22} U_{x}\right)+\frac{\partial}{\partial t}\left\{b\left(u_{x}-U_{x}\right)\right\}=-\Omega \frac{\partial p}{\partial x} \\
& \frac{\partial^{2}}{\partial t^{2}}\left(\rho_{21} u_{y}+\rho_{22} U_{y}\right)+\frac{\partial}{\partial t}\left\{b\left(u_{y}-U_{y}\right)\right\}=-\Omega \frac{\partial p}{\partial y} \\
& \frac{\partial^{2}}{\partial t^{2}}\left(\rho_{21} u_{z}+\rho_{22} U_{z}\right)+\frac{\partial}{\partial t}\left\{b\left(u_{z}-U_{z}\right)\right\}=-\Omega \frac{\partial p}{\partial z}
\end{aligned}
$$


骨格（粘弾性材）に関する運動方程式は以下となる.

$$
\begin{aligned}
& \frac{\partial^{2}}{\partial t^{2}}\left(\rho_{11} u_{x}+\rho_{12} U_{x}\right)+\frac{\partial}{\partial t}\left\{b\left(U_{x}-u_{x}\right)\right\}=\frac{\partial \sigma_{x}}{\partial x}+\frac{\partial \tau_{x y}}{\partial y}+\frac{\partial \tau_{x z}}{\partial z} \\
& \frac{\partial^{2}}{\partial t^{2}}\left(\rho_{11} u_{y}+\rho_{12} U_{y}\right)+\frac{\partial}{\partial t}\left\{b\left(U_{y}-u_{y}\right)\right\}=\frac{\partial \sigma_{y}}{\partial y}+\frac{\partial \tau_{y z}}{\partial z}+\frac{\partial \tau_{y x}}{\partial x} \\
& \frac{\partial^{2}}{\partial t^{2}}\left(\rho_{11} u_{z}+\rho_{12} U_{z}\right)+\frac{\partial}{\partial t}\left\{b\left(U_{z}-u_{z}\right)\right\}=\frac{\partial \sigma_{z}}{\partial z}+\frac{\partial \tau_{z x}}{\partial x}+\frac{\partial \tau_{z y}}{\partial y}
\end{aligned}
$$

$\Omega$ : 多孔度(Porosity), $s$ : 迷路度(Tortuosity), $\rho_{11}=\rho_{s}+\rho_{a}, \rho_{12}=-\rho_{a}, \rho_{22}=\rho_{f}+\rho_{a}, \quad \rho_{21}=-\rho_{a}$, $\rho_{s}=\rho_{1}(1-\Omega)$ と $\rho_{f}=\rho_{0} \Omega$ は骨格と空気を混合した体積を換算した密度, $\rho_{a}=\rho_{f}(s-1)$ : 骨格と空気との 連成に基づく密度, $\rho_{1}$ : 骨格の密度， $\sigma_{x}, \sigma_{y}, \sigma_{z}$ : それぞれ x,y,z 方向の垂直応力, $\tau_{x y}, \tau_{x z}, \tau_{y z}, \tau_{y x}$, $\tau_{z x}, \tau_{z y}$ : せん断応力, $b=\Omega r:$ 粘性連成項の係数, $r$ : 流れ抵抗である. 式(1)から式(6)の左辺第 2 項は, 骨 格の隙間を空気が通り抜ける時の内部摩擦に起因する粘性抵抗が, 内部空気と骨格の相対速度に対し作用するこ とを表す。

内部空気の圧縮の式は次式となる.

$$
-\Omega p=Q_{m} \operatorname{div}\{u\}+E_{m} \operatorname{div}\{U\}
$$

$E_{m}=\Omega E^{*}$ であり, $E^{*}$ は内部空気の複素体積弾性率である. $Q_{m}=(1-\Omega) E^{*}$ はカップリング弾性率である. 右辺の第 1 項は, 内部空気の圧力 $p$ と体積膨張率 $\operatorname{div}\{U\}$ の関係に骨格の体積膨張率 $\operatorname{div}\{u\}$ の影響があること を示す．これら弾性率が複素数となっているのはヒステリシス減衰を考慮したものである.

骨格（粘弾性体）の応力とひずみの関係は次式となる.

$$
\begin{aligned}
& \sigma_{x}=2 G_{s}^{*} \frac{\partial u_{x}}{\partial x}+A_{s}^{*} \operatorname{div}\{u\}+Q_{m} \operatorname{div}\{U\} \\
& \sigma_{y}=2 G_{s}^{*} \frac{\partial u_{y}}{\partial y}+A_{s}^{*} \operatorname{div}\{u\}+Q_{m} \operatorname{div}\{U\} \\
& \sigma_{z}=2 G_{s}^{*} \frac{\partial u_{z}}{\partial z}+A_{s}^{*} \operatorname{div}\{u\}+Q_{m} \operatorname{div}\{U\} \\
& \tau_{x y}=\tau_{y x}=G_{s}^{*}\left(\frac{\partial u_{x}}{\partial y}+\frac{\partial u_{y}}{\partial x}\right) \\
& \tau_{y z}=\tau_{z y}=G_{s}^{*}\left(\frac{\partial u_{y}}{\partial z}+\frac{\partial u_{z}}{\partial y}\right) \\
& \tau_{z x}=\tau_{x z}=G_{s}^{*}\left(\frac{\partial u_{z}}{\partial x}+\frac{\partial u_{x}}{\partial z}\right)
\end{aligned}
$$




$$
G_{s}^{*}=\frac{E_{s}\left(1+j \eta_{s}\right)}{2\left(1+v_{s}\right)}: \text { 骨格（粘弾性体）の複素せん断剛性率, } A_{s}^{*}=\frac{E_{s} v_{s}\left(1+j \eta_{s}\right)}{\left(1+v_{s}\right)\left(1+2 v_{s}\right)}
$$

$E_{s}, \eta_{s}, v_{s}$ はそれぞれ骨格のヤング率，材料損失係数，ポアソン比である．骨格の応力も内部空気の体積変 化の影響を $Q_{m} \operatorname{div}\{U\}$ の項で受けている. $G_{s}^{*}$ と $A_{s}^{*}$ が複素数になるのは骨格のヒステリシス減衰による制振効果 を考慮したものである.

内部空気の粒子変位ベクトル $\{U\}$ にはつぎの非回転条件を考慮した.

$$
\operatorname{rot}\{U\}=\{0\}
$$

式(1)から式(14)で, 圧力 $p$ を消去し整理すると内部空気の粒子変位 $\{U\}$ と骨格の変位 $\{u\}$ ま知数とする連立 微分方程式を得る. 次に要素内の内部空気の粒子変位 $\{U\}$ と接点の内部空気の粒子変位 $\left\{U_{e}\right\}$ の関係を, 内挿関 数行列 $\left[N_{U}\right]^{T}$ を用いて次式のように近似する.

$$
\{U\}=\left[N_{U}\right]^{T}\left\{U_{e}\right\}
$$

さらに要素内の骨格の粒子変位 $\{u\}$ と接点の骨格の粒子変位 $\left\{u_{e}\right\}$ の関係を, 内挿関数行列 $\left[N_{U}\right]^{T}$ を用いて次式 のように近似する。

$$
\{u\}=\left[N_{u}\right]^{T}\left\{u_{e}\right\}
$$

式(15), 式(16)を用い, $\{U\}$ と\{u\}についての連立微分方程式にガラーキン法を適用する. さらに弱形式にまと めると以下の離散化方程式を得る.

$$
\left.\left[\begin{array}{ll}
{\left[M_{11}\right]} & {\left[M_{12}\right]} \\
{\left[M_{21}\right]} & {\left[M_{22}\right]}
\end{array}\right]\left(\begin{array}{l}
\frac{\partial^{2} u_{e}}{\partial t^{2}} \\
\frac{\partial^{2} U_{e}}{\partial t^{2}}
\end{array}\right\}+\left[\begin{array}{ll}
{\left[C_{11}\right]} & {\left[C_{12}\right]} \\
{\left[C_{21}\right]} & {\left[C_{22}\right]}
\end{array}\right]\left\{\begin{array}{l}
\frac{\partial u_{e}}{\partial t} \\
\frac{\partial U_{e}}{\partial t}
\end{array}\right\}+\left[\begin{array}{ll}
{\left[K_{11}\right]} & {\left[K_{12}\right]} \\
{\left[K_{21}\right]} & {\left[K_{22}\right]}
\end{array}\right]\right\}\left\{\begin{array}{c}
u_{e} \\
U_{e}
\end{array}\right\}=\left\{\begin{array}{c}
f_{e} \\
F_{e}
\end{array}\right\}
$$

ただし，

$$
\begin{aligned}
& {\left[M_{11}\right]=\iiint_{e} \rho_{11}\left[N_{u}\right]\left[N_{u}\right]^{T} d x d y d z,} \\
& {\left[M_{12}\right]=\iiint_{e} \rho_{12}\left[N_{u}\right]\left[N_{U}\right]^{T} d x d y d z,} \\
& {\left[M_{21}\right]=\iiint_{e} \rho_{21}\left[N_{U}\right]\left[N_{u}\right]^{T} d x d y d z,} \\
& {\left[M_{22}\right]=\iiint_{e} \rho_{22}\left[N_{U}\right]\left[N_{U}\right]^{T} d x d y d z,} \\
& {\left[C_{11}\right]=\iiint_{e} b\left[N_{u} \llbracket\left[N_{u}\right]^{T} d x d y d z,\right.} \\
& {\left[C_{12}\right]=-\iiint_{e_{e}} b\left[N_{u}\right]\left[N_{U}\right]^{T} d x d y d z,} \\
& {\left[C_{21}\right]=-\iiint_{e_{e}} b\left[N_{U}\right]\left[N_{u}\right]^{T} d x d y d z,}
\end{aligned}
$$


$\left[C_{22}\right]=\iiint_{e} b\left[N_{U}\right]\left[N_{U}\right]^{T} d x d y d z$,

$\left[K_{11}\right]=\iiint_{e}\left[B_{u}\right][D]\left[B_{u}\right]^{T} d x d y d z$,

$\left[K_{12}\right]=\iiint_{Q_{e}} Q_{m}\left[B_{u} \rrbracket d\right]\left[B_{U}\right]^{T} d x d y d z$,

$\left[K_{21}\right]=\iiint_{e_{e}} Q_{m}\left[B_{U}\right][d]\left[B_{u}\right]^{T} d x d y d z$,

$\left[K_{22}\right]=\iiint_{e} E_{m}\left\{\frac{\partial\left[N_{U}\right]}{\partial x} \frac{\partial\left[N_{U}\right]^{T}}{\partial x}+\frac{\partial\left[N_{U}\right]}{\partial y} \frac{\partial\left[N_{U}\right]^{T}}{\partial y}+\frac{\partial\left[N_{U}\right]}{\partial z} \frac{\partial\left[N_{U}\right]^{T}}{\partial z}\right\} d x d y d z$,

$[D]=\frac{E_{s}\left(1-v_{s}\right)}{\left(1+v_{s}\right)\left(1-2 v_{s}\right)}\left[\begin{array}{cccccc}1 & \frac{v_{s}}{1-v_{s}} & \frac{v_{s}}{1-v_{s}} & 0 & 0 & 0 \\ \frac{v_{s}}{1-v_{s}} & 1 & \frac{v_{s}}{1-v_{s}} & 0 & 0 & 0 \\ \frac{v_{s}}{1-v_{s}} & \frac{v_{s}}{1-v_{s}} & 1 & 0 & 0 & 0 \\ 0 & 0 & 0 & \frac{1-2 v_{s}}{2\left(1-v_{s}\right)} & 0 & 0 \\ 0 & 0 & 0 & 0 & \frac{1-2 v_{s}}{2\left(1-v_{s}\right)} & 0 \\ 0 & 0 & 0 & 0 & 0 & \frac{1-2 v_{s}}{2\left(1-v_{s}\right)}\end{array}\right]$,

$\left[B_{u}\right]=[L]\left[N_{u}\right]^{T}, \quad\left[B_{U}\right]=[L]\left[N_{U}\right]^{T}$,

$[L]=\left[\begin{array}{ccc}\frac{\partial}{\partial x} & 0 & 0 \\ 0 & \frac{\partial}{\partial y} & 0 \\ 0 & 0 & \frac{\partial}{\partial z} \\ \frac{\partial}{\partial y} & \frac{\partial}{\partial x} & 0 \\ 0 & \frac{\partial}{\partial z} & \frac{\partial}{\partial y} \\ \frac{\partial}{\partial z} & 0 & \frac{\partial}{\partial x}\end{array}\right], \quad[d]=\left[\begin{array}{cccccc}1 & 1 & 1 & 0 & 0 & 0 \\ 1 & 1 & 1 & 0 & 0 & 0 \\ 1 & 1 & 1 & 0 & 0 & 0 \\ 0 & 0 & 0 & 0 & 0 & 0 \\ 0 & 0 & 0 & 0 & 0 & 0 \\ 0 & 0 & 0 & 0 & 0 & 0\end{array}\right]$

外カベクトル $\left\{F_{e}\right\},\left\{f_{e}\right\}$ を既知量として与えると式(17)は $\left\{U_{e}\right\},\left\{u_{e}\right\}$ についての複素連立1次方程式となる.

\section{$2 \cdot 2$ 固体に関する振動場の離散化}

固体（弾性体，粘弾性体）の振動場については，微小振幅を仮定し通常の 3 次元線形有限要素で離散化する. 粘弾性体についてはヤング率を複素数とすることでヒステリシス減衰を考慮した. 


\section{$2 \cdot 3$ 全系の離散化方程式}

固体と弾性多孔体の骨格が接着されている場合には, 境界で固体の変位と骨格の変位を x,y,z 方向で連続とした. 固体と骨格が接着されていない場合は x,y,z 方向で非常に弱いバネで結合した。一方，固体と弾性多孔体の内部空 気の境界では，境界面に対し垂直方向の変位を連続とした．以上の境界条件を考慮し対象とする場の全要素を重 放合わせて全系の離散化方程式を得る. 全系の離散化方程式は, 周期外力を与えると, 変位を未知数とする複素 連立 1 次方程式となるので，これをスカイライン法で解いて応答を計算した.

\section{3. 実験計測結果と解析結果}

\section{$3 \cdot 1 \quad$ 残響箱を用いた遮音性能計測結果}

図 2 に, 今回の計測で用いた半無響室に設置された簡易的な遮音性能計測装置（残響箱）を示す．外周が 1 辺 約 $1100 \mathrm{~mm}$ の直方体の箱の下面にスピーカーが設置されており，上面に設置するベースパネル（板厚 $0.8 \mathrm{~mm} の$ 鉄板）やその上に積層した吸遮音材を下面より音圧加振できる. 4 側面は, 鉄板, 砂, 鉄板, フェルト，ゴムの 5 重構造(厚さ計 $300 \mathrm{~mm}$ ) となっており, 上面以外から漏れる音は無視できるレベルであることを確認済みである. ベースパネルの $500 \mathrm{~mm}$ 上方にマイクが設置されており，同じ音圧で加振した際の音圧レベルの比（例えば，べ ースパネルに吸遮音材を積層した場合の音圧レベルとベースパネルのみの音圧レベルの比）により遮音性能を評 価できる.

図 3 に遮音性能の計測結果を示す. 図 3(a)はベースパネルに上（mic 側）から厚さ $20 \mathrm{~mm}$ の雑色 PET フェルト $800 \mathrm{~g} / \mathrm{m}^{2}$, 厚さ $0.04 \mathrm{~mm}$ のフィルム $35 \mathrm{~g} / \mathrm{m}^{2}$, 厚さ $20 \mathrm{~mm}$ の反毛フェルト $1550 \mathrm{~g} / \mathrm{m}^{2}$ の順に積層された吸遮音材 (以 後 sample(1)）のフィルムと上下フェルトの接着の有無の比較で, 図 3(b)がベースパネルに上から厚さ $5 \mathrm{~mm}$ の反 毛フェルト (バイダー25\%) $550 \mathrm{~g} / \mathrm{m}^{2}$, 厚さ $0.04 \mathrm{~mm}$ のフィルム $35 \mathrm{~g} / \mathrm{m}^{2}$, 厚さ $20 \mathrm{~mm}$ の反毛フェルト $1550 \mathrm{~g} / \mathrm{m}^{2} の$ 順に積層された吸遮音材（以後 sample(2)）のフィルムと上下フェルトの接着の有無の比較である. 接着は実際の 製品では整形時にフィルムが熱融着する仕組みだが，今回の試験では，全面スプレーのりを用いて接着した．フ エルトとフィルムの接着の有無により遮音性能が大きく変化していることがわかる．なお， sample(1), sample(2) とも一般的に自動車の吸遮音材に用いられている材料であり，本研究では他にも 2 種類（計 4 種類）の計測を行 っているが，接着と非接着で最も影響が小さかったのが sample(1)で，もっと影響が大きかったのが sample(2)であ り, 本論文に載せた次第である.また, 1 番上に積層したフェルトの密度の違いにより接着した際の遮音性能が 大きく異なるのがわかる．別途実施した数值計算によるパラメータスタディでも同様の傾向を示した．これは， 薄くて密度の高い（固い）フェルトの方が接着による剛性 Up の影響が大きい事を示している. 本現象のメカニズ ムについて $3 \cdot 3$ 節で明らかにする。
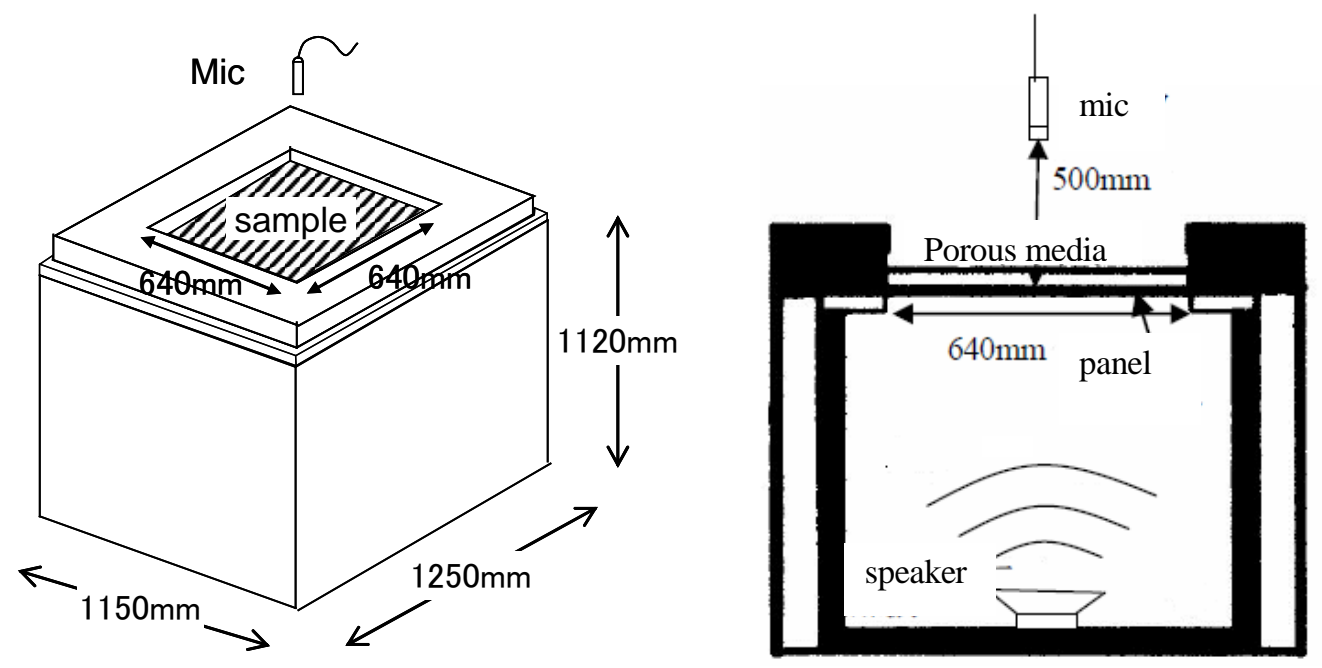

Fig.2 Experimental setup of sound insulation level 


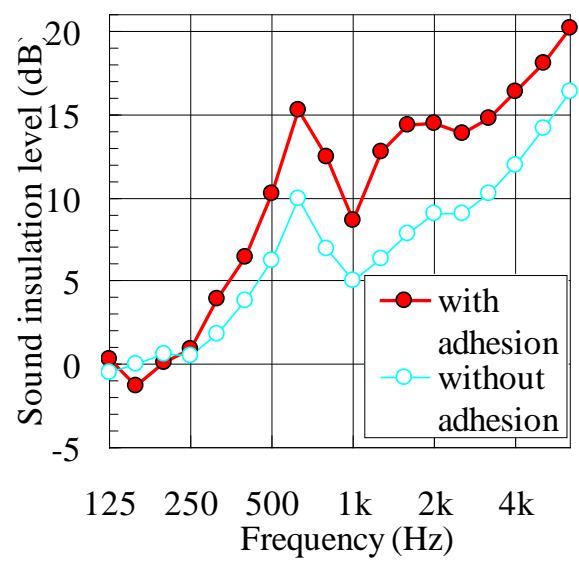

(a) Sample(1)

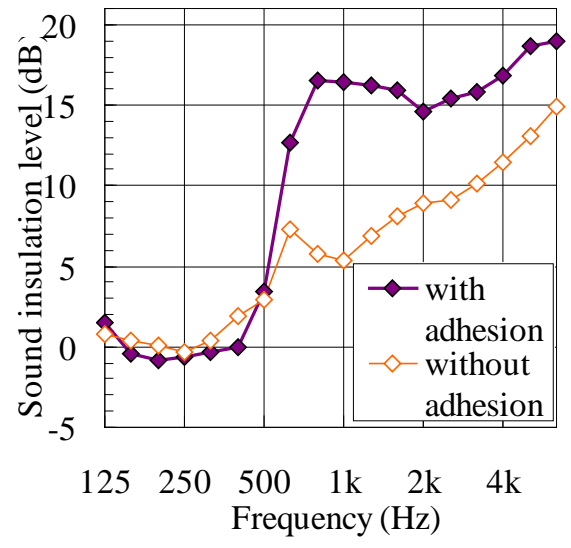

(b) Sample(2)

Fig.3 Experimental results of sound insulation level

\section{$3 \cdot 2$ ハンマー加振実験による解析精度検証}

第 2 章で説明した計算手法の精度検証を行った．前節で説明した残響箱を用いて，ベースパネルに厚さ $5 \mathrm{~mm}$ の反毛フェルト (バイダー25\%) $550 \mathrm{~g} / \mathrm{m}^{2}$ とフィルムを接着した吸遮音材を積層（パネルとフェルトは非接着）し て，フェルトを直径 $20 \mathrm{~mm}$ 程度くり抜きパネルをハンマー加振し，レーザードップラー振動計を用いて最上面の フィルムの応答レベルを計測した．フィルムはスプレーのりでフェルトに全面接着した．計測点 1 はパネル中心 の座標を $(0 \mathrm{~mm}, 0 \mathrm{~mm})$ とすると $(20 \mathrm{~mm}, 40 \mathrm{~mm})$ の位置で, 加振位置は $(20 \mathrm{~mm}, 20 \mathrm{~mm})$ である. 計測点 2 は $(260 \mathrm{~mm}$, $280 \mathrm{~mm}$ )の位置で, 加振位置は (260 mm, $260 \mathrm{~mm}$ )である (図 4(a)参照). 同じ条件の FE モデル（3.3 節で説明）を 作成して計測結果と比較したグラフを図 4(b)(c)に示す．0 [dB]=20* $\log 10\left(1\left[\mathrm{~m} / \mathrm{s}^{2} / \mathrm{N}\right]\right)$ である.ファーストピークま での剛性ラインや $200 \mathrm{~Hz}$ 以上の応答レベルが計算結果と計測結果で近い值となっており, 定性的に一致する傾向 であるといえる。 また，計測点 1 はパネルのほぼ中央で, 計測点 2 は拘束されている境界の近くであるため, 剛 性ラインは計測点 2 の方が小さく(岡性が大きく), $200 \mathrm{~Hz}$ 以上の応答レベルは計測点 1 のほうが大きい傾向は計 算結果にも現れており，合理的な結果であるといえる.よって，計算結果は計測結果をほぼ再現しているといえ る.

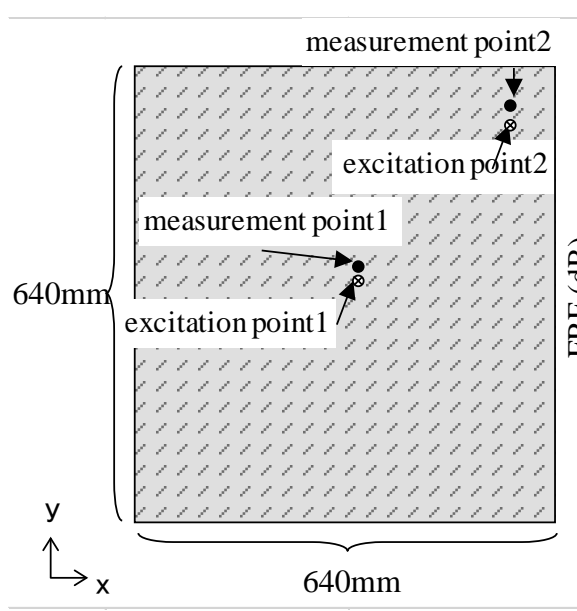

(a) Position for measurement and excitation

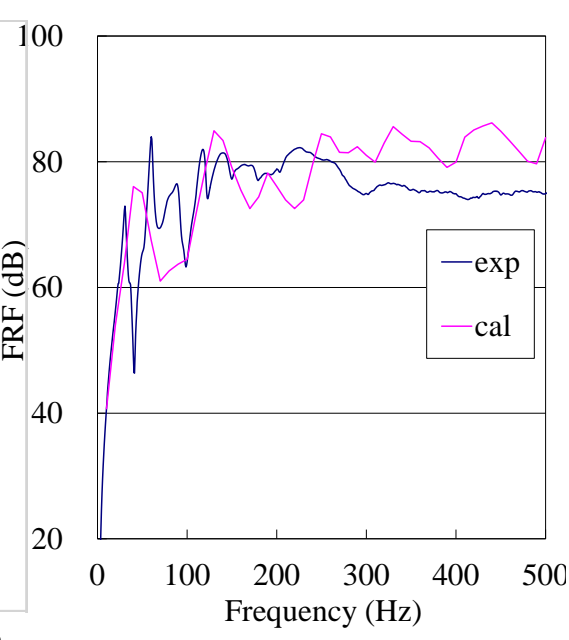

(b) Measurement point 1

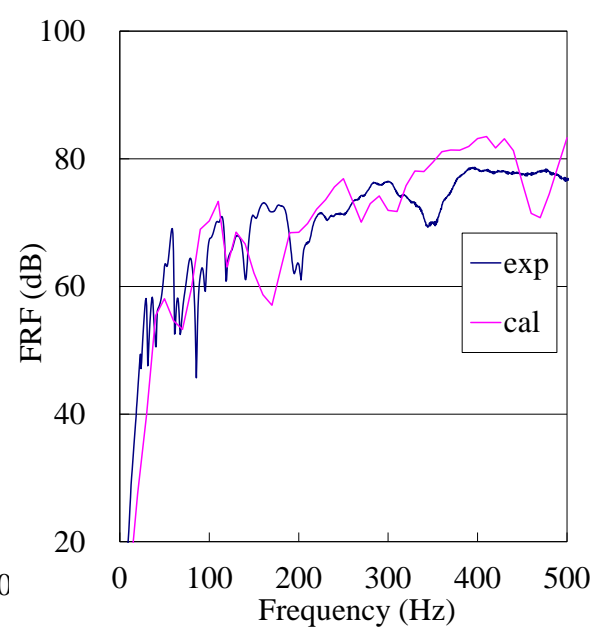

(c) Measurement point 2

Fig.4 Comparison of experimental results and calculation results

\section{$3 \cdot 3$ 実験結果と計算結果の比較}

次に残響箱を用いてペースパネルに仕様(2)の吸遮音材を積層させ，パネル下面からスピーカー加振を行いレー ザードップラー振動計で表層フェルトの振動を計測した。また，フェルト等を積層せずパネルのみの場合の振動 も計測した．計測位置は前節と同じ (図 4 参照) である. また，同様に FE モデルでパネル下面全点 $\mathrm{Z}$ 方向入力 
による応答を計算した．図 5 に今回用いた解析モデルを示す．計算モデル作製には Altair 社の Hypermesh を用い た．フェルトは内部空気と骨格でモデル化しており，右図はわかりやすく別に表したが，実際には同じ位置にあ り，各節点も同じ位置にあり第 2 章で示した連成項により相互作用をしている．パネルとフェルトの内部空気は 面外方向は連続，面内方向はフリーである，パネルと骨格は 3 方向を非常に弱いバネで連結した．フェルトの内 部空気とフィルムはパネルと同様の境界条件で, 骨格とフィルムは接着しているので 3 方向固いバネで連結した. パネルの周辺の境界条件は, あらかじめパネルのみの状態でハンマー加振実験を行いバネ係数をチューニングし た. モデル外周とフェルトの内部空気は，法線方向は拘束，接線方向はフリー，骨格は固いバネで拘束した。 フ イルムも拘束条件とした.

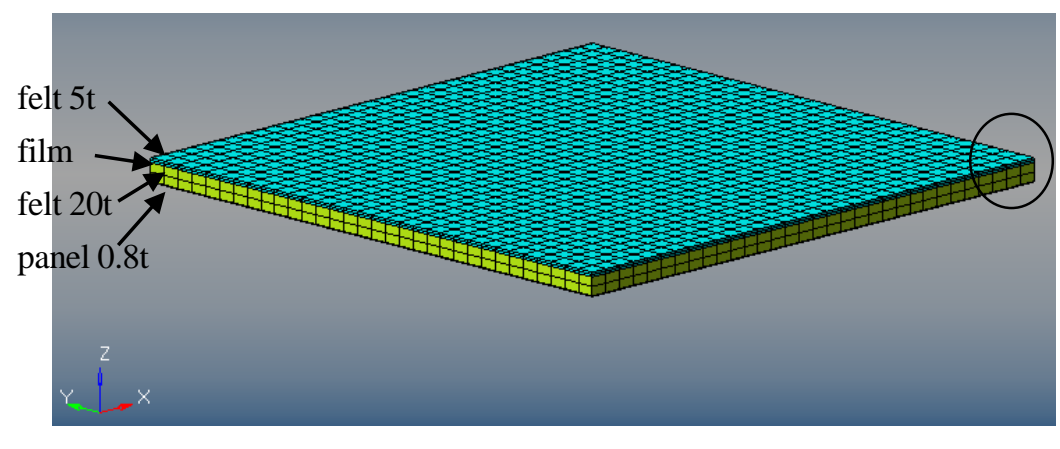

Fig.5 Analysis model

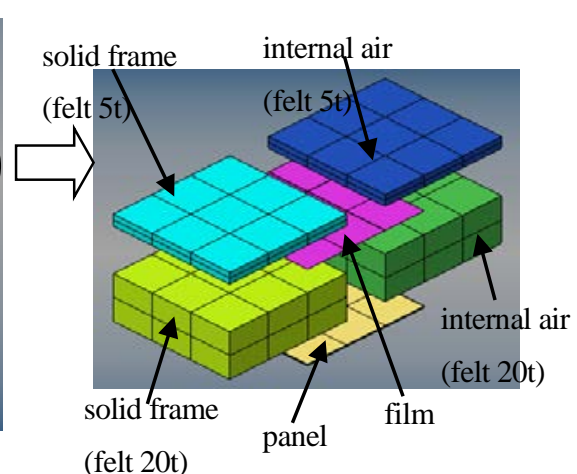

(felt 20t)

図 6 に計測点 1 , 図 7 に計測点 2 における実験結果（a）と計算結果（b）の比較を示す. どちらも吸遮音材を積 層させた表層フェルトの振動をパネルのみの振動で割って $\mathrm{dB}$ 表示したものを $1 / 3$ オクターブバンドごとに表示し たものである.一般的には振動レベルが高い方が遮音性能は低くなるが, 図 7 は比較を見やすくするため $1 / 3$ オ クターブバンドごとに值を平均していること（たとえば反共振の谷が平均を下げてしまう），また位相が考慮され ていない等の理由でこのような結果になったと考えられる，計測点 1 では，接着の有無による周波数ごとの振動 レベル差や接着時のピーク周波数が計算結果と計測結果で定性的に一致する傾向であること確認できたままた， 計測点 2 では接着の有無による振動レベル差が計測点 1 より小さいことや接着時のピーク周波数が計算結果と計 測結果で定性的に一致する傾向であること確認できた. 計測点 2 は拘束されている境界に近いため接着の有無に よる振動レベル差が計測点 1 より小さいので合理的な結果であるといえる. 以上より計算結果は接着有無のよる 影響の定性的な差を再現出来ているといえる.

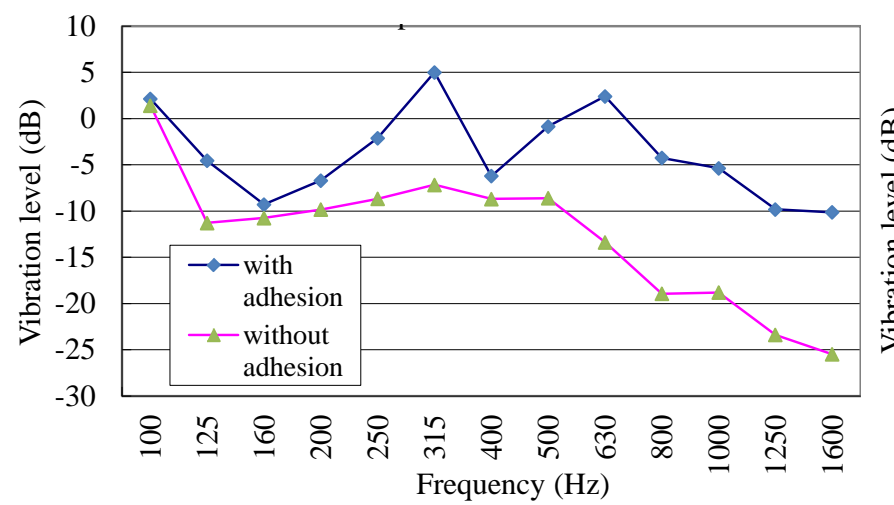

(a) Experimental results

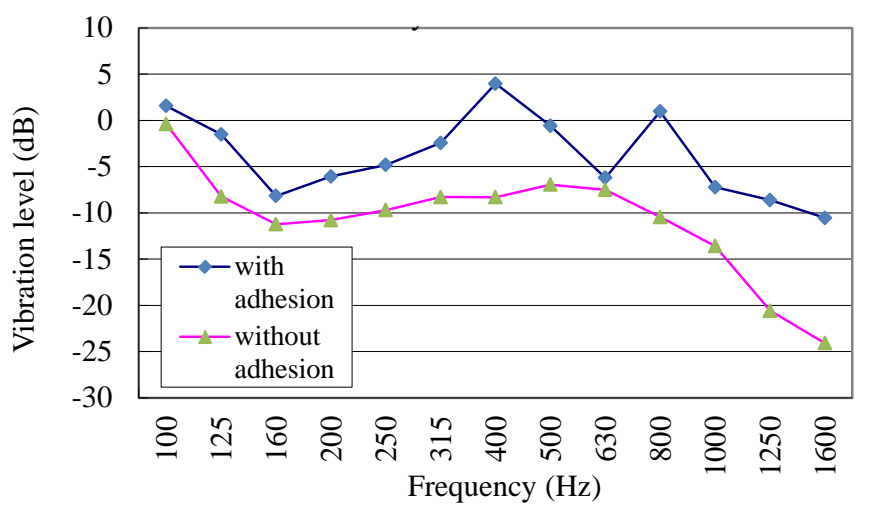

(b) Analysis results

Fig.6 Comparison of experimental results and calculation results (measurement point 1) 


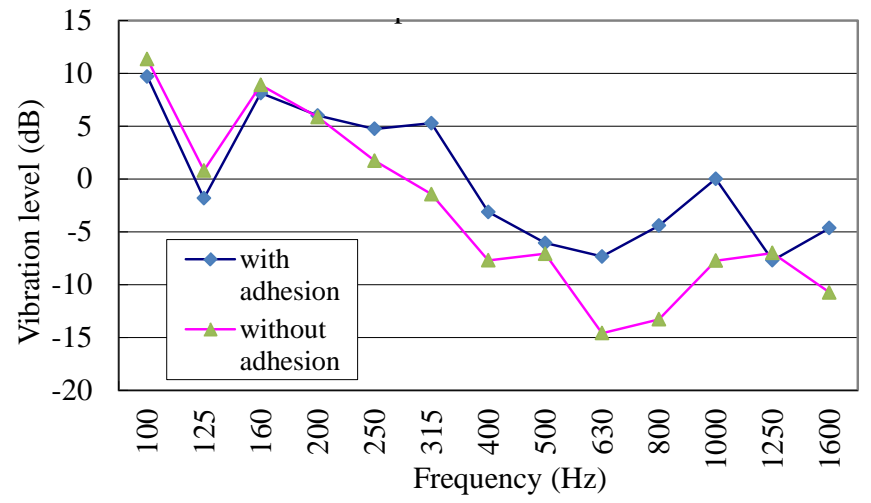

(a) Experimental results

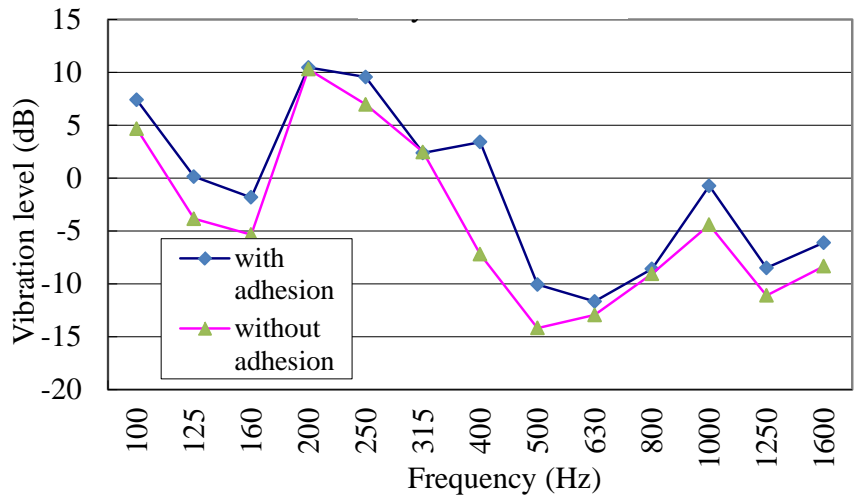

(b) Analysis results

Fig.7 Comparison of experimental results and calculation results (measurement point 2)

図 8 に計測点 1 における上部フェルトの内部空気と骨格の振動応答の計算結果の比較を示す.図 8(a)が接着時, 図 8(b)が非接着時を示す，接着時には，弾性多孔体の内部空気と骨格がほぼ同様の振動をするのに対し，非接着 時は大きく異なる振動をしていることが確認できた. 図 3(b)では $500 \mathrm{~Hz}$ を境に接着の有無の遮音性能が逆転して おり，図 8(b)も $500 \mathrm{~Hz}$ を境に骨格と内部空気の振動レベルが逆転しており，遮音性能の変化に影響していると考 えられる. 図 9 に $1000 \mathrm{~Hz}$ における接着時・非接着時の振動変位分布をコンター表示した. 赤い部分が振幅大, 青い部分が振幅小で，図 9(a)が接着時，図 9(b)が非接着時である. どちらの場合も上下のフェルトの内部空気は 同様の変位を示しているのに対し, 非接着時は骨格と内部空気でまったく異なる振動分布をしている. 図 9(b)よ り非接着時は入力側（felt 20t）より応答側(felt 5t)の方が骨格の振動レベルが大きくなっており，接着時に比べ遮 音性能が小さくなっている可能性が考えられる.

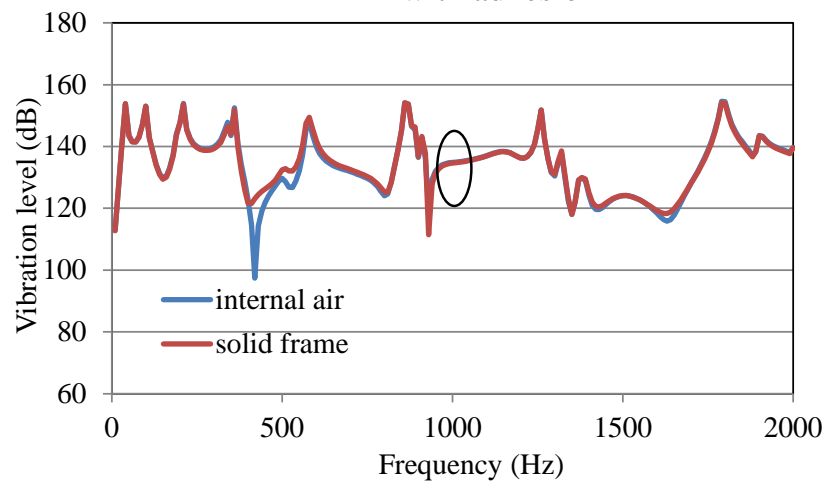

(a) With adhesion

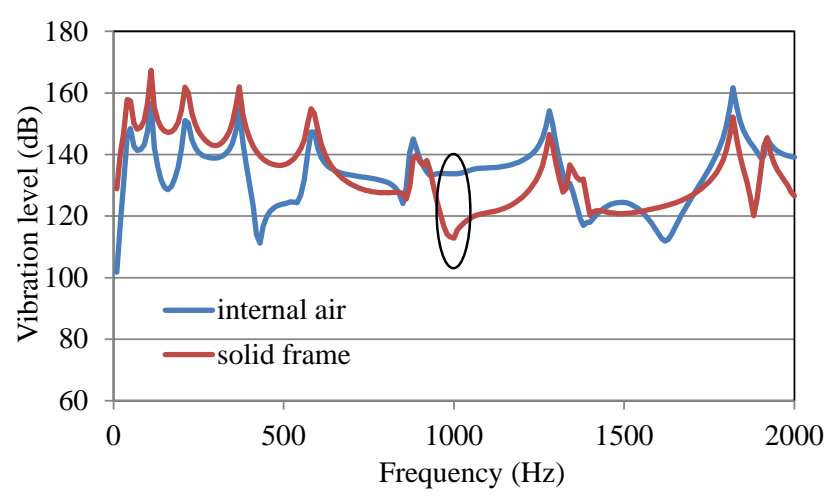

(b) Without adhesion

Fig.8 Comparison of response levels for internal air and solid frame

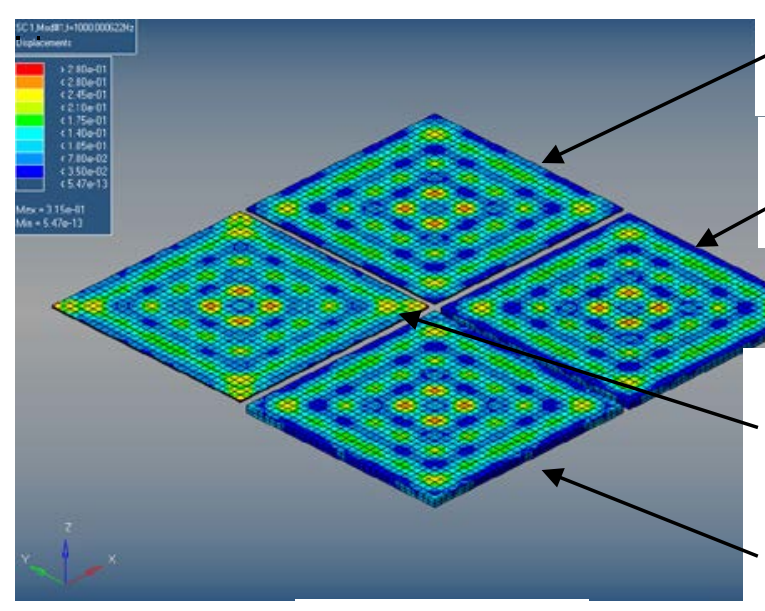

(a) With adhesion

Fig.9 Comparison of vibration for internal air and solid frame $(1000 \mathrm{~Hz})$ 


\section{4. 結言}

半無響室に設置された簡易的な遮音性能計測装置（残響箱）を用いて，パネルにフェルトとフィルム (オレフィン シート）とフェルトが積層された自動車用吸遮音材の遮音性能を計測した。フィルムが上下フェルトと接着された場 合と接着されていない場合で遮音性能が大きく変化することを確認した．また，フェルトの密度により変化代が 変わることも確認した.

音圧加振時の表層フェルトの振動をレーザードップラー振動計で計測した．接着時と非接着時で振動レベルが 変化している事を確認した，本現象を解明するため，Biot 理論を用いた弾性多孔体の有限要素法を用いて積層吸 遮音材の振動計算を行った．計算結果は計測結果と同様の傾向を示すことを確認した．また，接着時には，弾性 多孔体の内部空気と骨格が同様の振動をするのに対し, 非接着時は大きく異なる振動をしており, これにより遮 音性能の変化が起こると考えられる.

\section{文献}

Atalla, N. and Gardner, B., Foam-module theory manual, Vibro-acoustic sciences, Inc. (2001).

Allard, J. F. and Atalla, N., Propagation of sound in porous media, John Wiley \& Sons, Inc.(2009).

Biot, M. A., Theory of propagation of elastic waves in a fluid-saturated porous solid (1. Higher frequency range), The Journal of the Acoustical Society of America, 28-2 (1955), pp.168-191.

Kang, Y. J. and Bolton, S., A finite element model for sound transmission through foam-lined double panel structures, The Journal of the Acoustical Society of America, 99(1996), pp.2755-2765.

黒沢良夫，中泉直之，高橋学，山口誉夫，吸遮音材を積層したパネルの振動と透過損失，Dynamics and Design Conference 2013, No.262 (2013).

黒沢良夫, 中泉直之, 高橋学, 山口誉夫, フェルトとフィルムを積層したパネルの遮音性能解析, Dynamics and Design Conference 2014, No.647 (2014).

山口誉夫, 黒沢良夫, 松村修二, 固体-多孔体-空気からなる防音構造の減衰特性の FEM 解析, 日本機械学会論文 集 C 編, Vol.69, No.677 (2003), pp.34-41.

山口誉夫, 中本英良, 黒沢良夫, 松村修二, 弾性体-粘弾性体-多孔体からなる自動車防音構造のサウンドブリッジ の散冕エネルギの FEM 解析, 日本機械学会論文集 C 編, Vol.71, No.708(2005), pp.2477-2484.

山口誉夫, 山本崇史, 丸山新一, FEM による Biot タイプ多孔質材を含む積層構造の変形と振動減衰の解析, Dynamics and Design Conference 2006, No.728 (2006).

\section{References}

Atalla, N. and Gardner, B., Foam-module theory manual, Vibro-acoustic sciences, Inc. (2001).

Allard, J. F. and Atalla, N., Propagation of sound in porous media, John Wiley \& Sons, Inc.(2009).

Biot, M. A., Theory of propagation of elastic waves in a fluid-saturated porous solid (1. Higher frequency range), The Journal of the Acoustical Society of America, 28-2 (1955), pp.168-191.

Kang, Y. J. and Bolton, S., A finite element model for sound transmission through foam-lined double panel structures, The Journal of the Acoustical Society of America, 99(1996), pp.2755-2765.

Kurosawa, Y., Nakaizumi, N., Takahashi, M. and Yamaguchi, T., Vibration and Transmission loss for panels laminated with porous media, Dynamics and Design Conference 2013, No.262 (2013) (in Japanese).

Kurosawa, Y., Nakaizumi, N., Takahashi, M. and Yamaguchi, T., Transmission loss analysis for panels laminated with felt and film, Dynamics and Design Conference 2014, No.647 (2014) (in Japanese).

Yamaguchi, T., Kurosawa, Y. and Matsumura, S., Finite element analysis for damping properties of sound-proof structures having solid body, porous media and air, Transactions of the Japan Society of Mechanical Engineers, Series C, Vol.69, No.677 (2003), pp. 34-41 (in Japanese).

Yamaguchi, T., Nakamoto, H., Kurosawa, Y. and Matsumura, S., Dynamic analysis of dissipated energy for automotive sound-proof structures including elastic body, viscoelastic body and porous body using FEM in sound bridge phenomena, Transactions of the Japan Society of Mechanical Engineers, Series C, Vol.71, No.708 (2005), pp. 2477-2484 (in Japanese).

Yamaguchi, T., Yamamoto, T. and Maruyama, S., FEM for deformations and vibration damping in laminates including biot 
Kurosawa, Yamaguchi, Nakaizumi and Takahashi, Transactions of the JSME (in Japanese), Vol.82, No.837 (2016) type porous material, Dynamics and Design Conference 2006, No.728 (2006) (in Japanese). 